JAMP: Jurnal Adminitrasi dan Manajemen Pendidikan Volume 1 Nomor 3 September 2018, Hal : 263-269

Tersedia Online di http://journal2.um.ac.id/index.php/jamp/ ISSN 2615-8574 (online)

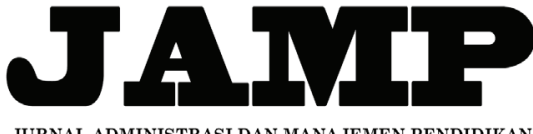

JURNAL ADMINISTRASI DAN MANAJEMEN PENDIDIKAN

\title{
SISTEM PENGELOLAAN GURU TIDAK TETAP (GTT) DALAM PENINGKATAN MUTU PENDIDIKAN
}

\author{
Milla Rahayu \\ Nurul Ulfatin \\ Juharyanto \\ E-mail : millarahayu96@gmail.com \\ Universitas Negeri Malang, Jl. Semarang No. 5 Malang 65145
}

\begin{abstract}
A teachers have a very important role in the achievement of a goal education. Basically management teachers fully had an enormous impact and regarded as the key in improving the quality of education. Yet management teachers was intended to produce professional teachers so that it can be created an output that capable, having budi sublime are good and profitable to the nation. The development of science and technology ( science and technology ) then the system education also increase significantly, this might impact on the needs teachers. This Non Permanent Teacher (GTT) also has the status a very vital at the school due to the presence of gtt very petrified school.The majority gtt is those who can afford to controls science and in accordance with the developments of the times.
\end{abstract}

Keyword: Needs, Recruitment, Selection, Compensation.

\begin{abstract}
Abstrak: Guru mempunyai peranan yang sangat penting dalam pencapaian tujuan pendidikan. Pada dasarnya pengelolaan guru sepenuhnya mempunyai pengaruh yang sangat besar dan dianggap sebagai kunci utama dalam meningkatkan mutu pendidikan. Hakikatnya pengelolaan guru bertujuan untuk menghasilkan guru yang profesional sehingga dapat menciptakan output yang cakap, memiliki budi luhur yang baik dan berguna bagi bangsa. Semakin berkembangnya Ilmu Pengetahuan dan Teknologi (IPTEK) maka sistem pendidikan juga ikut meningkat, hal ini berdampak pada kebutuhan guru. Guru Tidak Tetap (GTT) juga memiliki kedudukan yang sangat vital disekolah karena keberadaan GTT sangat membatu sekolah. Mayoritas GTT adalah mereka yang mampu menguasi Ilmu Pengetahuan dan Teknologi (IPTEK) sesuai dengan perkembangan zaman.
\end{abstract}

Kata kunci: Kebutuhan, Rekrutmen, Seleksi, Kompensasi.

Pendidikan merupakan sektor yang sangat menentukan kualitas suatu bangsa. Kegagalan pendidikan berimplikasi pada gagalnya suatu bangsa. Keberhasilan pendidikan juga secara otomatis membawa keberhasilan suatu bangsa. Hal ini sesuai dengan salah satu tujuan nasional bangsa Indonesia sebagaimana tertuang dalam pembukaan Undang-Undang Dasar Negara Republik Indonesia tahun 1945 adalah mencerdaskan kehidupan bangsa, dimana hal tersebut merupakan upaya pemerintah dalam pembangunan nasional di bidang pendidikan dan diwujudkan dengan meningkatnya kualitas manusia Indonesia yang beriman, bertakwa, dan berakhlak mulia serta menguasai ilmu pengetahuan, teknologi, dan seni serta dalam mewujudkan masyarakat yang maju, adil, makmur dan beradab berdasarkan Pancasila dan Undang-Undang Dasar Negara Republik Inonesia Tahun 1945.

Peningkatan mutu pendidikan, baik pendidikan formal, pendidikan non formal dan pendidikan informal, tidak terlepas dari keberadaan guru. Dalam melaksanakan perannya, guru dituntut memiliki moral kerja yang baik. Selain itu, peningkatan mutu pendidikan salah satunya juga dipengaruhi oleh kompetensi guru (pendidik) artinya bahwa peran guru merupakan faktor yang utama dalam peningkatan 
mutu pendidikan. upaya peningkatan mutu pendidikan adalah perlunya peningkatan kwalitas secara keseluruan komponen ssstem pendidikan, baik yang berupa sumber daya manusia maupun berupa sumber daya material.

Dalam upaya peningkat mutu pendidikan, komponen pendidikan yang berupa sumber daya manusia (SDM) mempunyai peranan yang sangat penting dalam pencapaian tujuan yang diinginkan. Oleh karena itu para pimpinan lembaga pendidikan perlu memberikan perhatian yang serius terhadap pengelolaan sumber daya manusia yang terlibat di dalamnya, bukan hanya guru, kepala sekolah dan karyawan tetapi juga para siswa, wali siswa dan masyarakat. Karena hanya dengan kesiapan guru yang akan mampu membawa lembaga pendidikan tetap susvive dan bisa meningkatkan mutu pendidikan.

Pada dasarnya pengelolaan guru sepenuhnya mempunyai pengaruh yang sangat besar dan dianggap sebagai kunci utama dalam meningkatkan mutu pendidikan. Hal ini dapat difahami dari kenyataan bahwa keseluruhan sumber daya yang terdapat dalam lembaga pendidikan dalam hal ini guru merupakan satu-satunya sumber daya yang memiliki akal, perasaan keinginan, kemampuan, keterampilan dan pengetahuan. Potensi yang dimiliki guru tersebut juga berpengaruh dalam mencapai tujuan organisasi, karena betapapun maju dan canggihnya teknologi, berkembangnya informasi, tersedianya sarana dan prasarana yang memadai, namun tanpa guru yang handal maka tujuan organisasi sulit akan dicapai.

Profesi guru merupakan pekerjaan yang mulia. Tugas guru adalah memberikan ilmu agama, pengetahuan, pengalaman, penanaman nilai-nilai budaya dan moral. Guru juga sebagai seorang panutan yang "digugu dan ditiru" dan sebagai contoh bagi kehidupan dan pribadi peserta didiknya, artinya baik atau buruknya perilaku peserta didik merupakan cerminan dari gurunya (Roqib \&Nurfuadi, 2009).

Kehadiran guru di tengah-tengah masyarakat merupakan unsur yang penting. Karena guru merupakan sumber pencerahan dan suri tauladan sehingga manusia dapat belajar dan berkembang. Upaya guru dalam mendidik, membimbing, mengajar dan melatih peserta didik bukanlah hal yang mudah, namun hal tersebut membutuhkan keseriusan. Karena pada dasarnya manusia tidak akan memiliki budaya, norma, agama, ilmu pengetahuan dan teknologi jika tidak ada guru.

Dengan demikian usaha memperbaiki kualitas pendidikan merupakan suatu keharusan yang perlu direncanakan dengan baik dan terstruktur. Terutama keberadaan guru yang selalu menjadi pusat perhatian dalam kaitannya dengan pendidikan. Sorotan luas terhadap keberadaan guru menandakan pentingnya guru dalam menjalankan roda sistem pendidikan. Untuk itu permasalah guru dalam sistem pendidikan bangsa ini perlu diperhatikan, mulai dari masalah kekurangan guru, rekrutmen guru, pemerataan guru, kesejahteraan guru dan sebagainya.

Sesuai dengan Peraturan Pemerintah Nomor 19 Tahun 2017 tentang guru bahwa permasalahan yang dihadapi kedepan dalam pelaksanaan tata kelola pendidik salah satunya yaitu ketersediaan guru yang merata dengan cara meningkatkan perencanaan kebutuhan, penyediaan, pengangkatan, distribusi dan pemerataan guru. Selain itu, perlu meningkatkan kapasitas daerah dalam mengelola perekrutan, penempatan dan peningkatan mutu guru secara efektif dan efisien, mengawal proses pengangkatan guru di daerah berdasarkan kriteria mutu dan kebutuhan serta meningkatan koordinasi penyelenggaraan pendidikan oleh Lembaga Pendidik dan Tenaga Kependidikan dengan rencana penyediaan guru di daerah.

Pada hakikatnya pengelolaan guru bertujuan untuk menghasilkan guru yang profesional sehingga dapat menciptakan output yang cakap, memiliki budi luhur yang baik dan berguna bagi bangsa. Untuk itu dalam proses pengelolaan guru harus dilakukukan dengan benar dan sesuai dengan prosedur. Sebab apabila salah dalam mengelola guru maka akan bedampak pada kelangsungan pendidikan terutama yang terkena dampak langsung adalah peserta didik.

Selain itu guru merupakan bagian dari Aparatur Sipil Negara yang betugas di lembaga pendidikan untuk mengajar dan membimbing peserta didik. Status profesi guru yang ada di lembaga pendidikan terdiri dari guru tetap (PNS) dan guru tidak tetap/guru kontrak (GTT). Hal ini sesuai dengan UndangUndang ASN Nomor 5 Tahun 2014 menjelaskan bahwa Aparatur Sipil Negara yang selanjutnya disingkat ASN adalah profesi bagi pegawai negeri sipil dan pegawai pemerintah dengan perjanjian kerja yang bekerja pada instansi pemerintah. 
Perbedaan status kepegawaian para guru yang ada di lembaga pendidikan tentunya menimbulkan persoalan yang di hadapi oleh masing-masing guru baik dari segi finansial, rekrutmen, seleksi. Karena pada dasarnya ada perbedaan yang menonjol dari segi finansial guru tidak tetap (GTT) dengan guru PNS. Guru PNS tentunya gaji yang diterima cukup besar di banding GTT, bagaimana tidak, gaji guru PNS sudah diatur dalam perundang-undangan sedangkan untuk GTT tidak ada dasar hukum yang jelas. Sementara perbedaan yang tidak kalah pentingnya adalah sistem rekrutmen dan seleksi guru PNS dengan GTT. Sistem seleksi guru PNS dilakukan secara terbuka dan terstruktur, artinya adalah calon guru yang ingin mengikuti seleksi CPNS harus memiliki persyaratan serta mengikuti tahapan seleksi CPNS yang telah ditentukan oleh masing-masing daerah.

Kota Kediri bukan merupakan Kota Pendidikan layaknya Kota Malang dan Kota Surabaya yang ada di Jawa Timur. Anggapan tersebut sudah dikenal dikalangan masyarakat. Kota Kediri bukan merupakan Kota terpencil sehingga Kota ini masuk dalam kategori yang terkena dampak kebijakan pemerintah tentang Moratorium CPNS dalam hal ini adalah guru. Dampak yang dirasakan adalah banyak guru PNS yang pensiun namun kebutuhan guru semakin meningkat. Untuk mengatasi hal tersebut sekolah melakukan rekrutmen guru sendiri berdasarkan kontrak kerja atau yang sering disebut dengan Guru Tidak Tetap (GTT).

Sementara itu, GTT di Kota Kediri juga memiliki kedudukan yang sangat vital disekolah karena keberadaan GTT sangat membatu sekolah. Mayoritas GTT adalah mereka yang baru lulus di suatu lembaga pendidikan sehingga mereka mampu menguasi Ilmu Pengetahuan dan Teknologi (IPTEK) sesuai dengan perkembangan zaman dibanding dengan guru PNS yang mayoritas hampir mendekati masa pensiun. Perbedaan status guru ini tidak menjadikan alasan untuk tetap terpacu dalam meningkatkan kualitas pendidikan. Guru PNS dan GTT memiliki peran yang sama pada lembaga pendidikan. Mereka sama-sama mengabdi pada negara untuk membantu dalam melaksanakan tujuan negara.

Banyak hal yang menjadikan dasar bahwa keberadaan GTT justru membantu sekolah ataupun malah menjadi persoalan bagi setiap daerah. Karena munculnya GTT ini tidak dilakukan dengan prosedur rekrutmen dan seleksi yang benar. Sehingga menghasilkan guru yang tidak cakap dari segi kompetensinya. Selain itu minimnya anggaran yang digunakan untuk menggaji GTT, hal tersebut yang menjadi persoalan karena GTT hanya menerima gaji sesuai dengan ketentuan yang telah ditetapkan pada penggunaan anggaran Bantuan Operasional Sekolah (BOS).

Namun tidak mungkin apabila daerah tidak mengangkat GTT. Karena apabila sekolah membutuhkan guru dengan cepat maka solusinya adalah mengangkat GTT. Seperti halnya di Kota Kediri banyak jumlah GTT yang menduduki di suatu sekolah. Keberadaan GTT di Kota Kediri justru sangat membantu sekolah untuk kelancaran proses administrasi sekolah dan kegiatan belajar di sekolah. Banyak GTT yang mendapatkan tugas tambahan untuk membantu kepala sekolah dalam menjalankan tugas yang diberikan oleh Dinas Pendidikan Kota Kediri.

\section{METODE}

Penelitian ini menggunakan pendekatan kualitatif karena ingin menggali informasi secara mendalam mengenai manajemen sumber daya manusia bagi GTT. Teknik pengumpulan data yang digunakan dalam penelitian ini adalah wawancara, observasi dan dokumentasi. Data yang dikumpulkan pada penelitian ini adalah data yang berkaitan dengan perencanaan kebutuhan GTT, proses rekrutmen GTT, proses seleksi GTT serta kompensasi dan keselamatan kerja bagi GTT.

Pada penelitian ini menggunakan sumber data sekunder dan primer. Sumber data sekunder merupakan sumber data pendukung dalam penelitian berupa dokuman-dokumen yang dimiliki oleh bagian ketenagaan Dinas Pendidikan dan satu sekolah yang berkaitan dengan manajemen sumber daya manusia bagi GTT. Sedangkan sumber data primer yaitu sember data yang diperoleh melalui wawancara dengan Kepala Bidang Ketenagaan/ Kepala Seksi PTK Dinas Pendidikan serta kepada salah satu Kepala Sekolah dan GTT. Wawancara yang dilakukan oleh peneliti adalah wawancara terbuka yaitu informan mengetahui maksud dan tujuan peneliti dari wawancara tersebut. 


\section{HASIL}

\section{Perencanaan Kebutuhan GTT}

Langkah yang ditempuh sekolah di Kota Kediri dalam melakukan analisis kebutuhan adalah memperhatikan anggaran karena sekolah hanya memiliki satu sumber pendapatan yang pada dana Bantuan Operasional Sekolah (BOS), jika anggaran yang digunakan untuk menggaji GTT mencukupi maka sekolah diperbolehkan untuk mengangkat guru baru dalam hal ini adalah GTT, namun jika anggaran tidak mencukupi maka sekolah tidak diperkenankan untuk mengangkat GTT terutama adalah sekolah Negeri. Selain itu dalam melakukan analisis kebutuhan perlu memperhatikan kualifikasi guru yang dibutuhkan sekolah, hal ini dikarenakan untuk mengantisipasi supaya sekolah tidak salah dalam melakukan perekrutan GTT.

\section{Proses Rekrutmen GTT}

Proses rekrutmen GTT di Kota Kediri langkah pertama yang ditempuh adalah mengumumkan lowongan guru kepada warga sekolah. Sekolah tidak mengumumkan lowongan kepada masyarakat luas untuk mengantisipasi banyaknya jumlah pelamar yang ingin mendaftar sebab sekolah tidak memiliki anggaran untuk mengumumkan lowongan kepada media massa. Dalam rekrutmen GTT sekolah juga perlu mempersiapkan sarana dan prasarana yang diperlukan pada saat melakukan perekrutan GTT. Dalam hal ini adalah teknik pelaksanaan dalam perekrutan GTT. Sementara kendala yang dihadapi dalam proses rekrutmen adalah banyaknya jumlah pelamar, tidak adanya dasar hukum dalam perekrutan GTT sehingga kepala sekolah harus membuat kebijakan sendiri tentang rekrutmen GTT, tidak adanya komponen dalam penggunaan Bantuan Operasional Sekolah untuk anggaran dalam perekrutan GTT, serta adanya sistem "titip" bagi pejabat dalam perekrutan GTT.

\section{Proses Seleksi GTT}

Proses seleksi guru tidak tetap (GTT) di Kota Kediri ada beberapa tahapan yang perlu persiapan oleh calon guru. Tahap pertama adalah seleksi administrasi, dalam seleksi administrasi hal-hal yang perlu dipersiapkan oleh pelamar meliputi : (1) mengajukan lamaran yang ditujukan kepada kepala sekolah, lamaran ditulis pada kertas putih menggunakan tinta hitam (bukan diketik); (2) calon guru tidak tetap (GTT) memiliki kualifikasi pendidikan Sarjana (S1) sesuai dengan program studi yang butuhkan sekolah, program studi yang dicari sekolah tidak hanya dari mereka yang lulusan pendidikan namun sekolah memberikan peluang kepada pelamar dari program studi non pendidikan; (3) calon guru tidak tetap (GTT) wajib memiliki akta mengajar yaitu akta IV; (4) calon guru tidak tetap (GTT) yang berasal dari non pendidikan bersedia melaksanakan pendidikan linierisasi jika dibutuhkan. Sementara untuk tahap yang kedua adalah seleksi wawancara, dalam seleksi wawancara hal yang perlu diperhatikan oleh sekolah dalah keadaan fisik calon guru. Guru dituntut untuk tidak memiliki kekurangan fisik yang dapat menghambat kegiatan belajar mengajar (KBM) di sekolah.

\section{Kompensasi bagi GTT}

Kompensasi yang di terima GTT di Kota Kediri terdiri dari (1) kompensasi atau gaji pokok yang diperoleh GTT berasal dari dana Bantuan Operasional Sekolah (BOS). GTT bekerja berdasarkan kontrak kerja dengan jangka waktu 1 tahun; (2) GTT memperoleh insentif tambahan yang bersumber dari APBD Pemerintah Kota Kediri; (3) GTT memperoleh insentif tambahan dari sekolah apabila menjadi pembina kegiatan ekstrakurikuler di sekolah. Selain itu Guru Tidak Tetap (GTT) di Kota Kediri juga mendapatkan asuransi keselamatan kerja melalui kerjasama dengan Badan Penyelenggaran Jaminan Sosial (BPJS) cabang Kediri. Hal ini dilakukan untuk memberikan rasa aman kepada GTT dalam mengabdi pada sekolah. 


\section{PEMBAHASAN}

\section{Perencanaan Kebutuhan GTT}

Hasil penelitian menunjukkan bahwa dalam melakukan analisis kebutuhan bagi GTT sekolah memperhatikan anggaran yang dimiliki sebab sekolah sendiri hanya memiliki satu sumber pendapatan yaitu dana Bantuan Operasional Sekolah (BOS). Selain memperhatikan anggaran sekolah juga perlu memperhatikan kualifikasi guru yang dibutuhkan supaya tidak salah merekrut calon GTT.

Temuan tentang perencanaan kebutuhan guru di dukung teori yang di kemukakan oleh Ulfatin \& Triwiyanto (2016:36) cakupan perencanaan harus mengandung unsur-unsur meliputi : (1) Anggaran, anggaran harus diketahui dalam perencanaan karena menjadi dasar untuk pemberian kompensasi. Jika anggaran yang tersedia tidak menjadi kendala, maka perencanaan tidak banyak menghadapi persoalan. Tetapi jika anggaran menjadi kendala, maka langkah lain yang harus dipikirkan adalah mencari sumber anggaran baru atau realokasi kembali anggaran yang sudah ada; (2) Standar, standar yang harus ditentukan dalam perencanaan adalah standar yang mencakup jumlah (kuantitas) dan mutu (kualitas).

\section{Proses Rekrutmen GTT}

Hasil penelitian menunjukkan bahwa proses rekrutmen GTT oleh sekolah tahap pertama yang dilakukan adalah mengumumkan lowongan guru kepada warga sekolah Sekolah tidak mengumumkan lowongan kepada masyarakat luas untuk mengantisipasi banyaknya jumlah pelamar yang ingin mendaftar sebab sekolah tidak memiliki anggaran untuk mengumumkan lowongan kepada media massa. Tahap kedua adalah mempersiapkan sarana dan prasarana yang diperlukan pada saat melakukan perekrutan GTT. Dalam hal ini adalah teknik pelaksanaan dalam perekrutan GTT.

Temuan tentang perencanaan kebutuhan guru di dukung teori yang di kemukakan oleh Simamora (2006) sumber-sumber rekrutmen yang dapat di gunakan salah satunya adalah Referrals (rekomendasi pegawai), yaitu dapat merekomendasikan teman atau rekan sejawat profesional untuk sebuah lowongan.

\section{Proses Seleksi GTT}

Hasil penelitian menunjukkan bahwa kendala yang dihadapi dalam proses seleksi GTT meliputi seleksi administrasi dan seleksi wawancara. Dalam seleksi administrasi hal-hal yang perlu dipersiapkan oleh pelamar adalah (1) mengajukan lamaran yang ditujukan kepada kepala sekolah, lamaran ditulis pada kertas putih menggunakan tinta hitam (bukan diketik); (2) calon GTT memiliki kualifikasi pendidikan Sarjana (S1) sesuai dengan program studi yang butuhkan sekolah; (3) calon guru tidak tetap (GTT) wajib memiliki akta mengajar yaitu akta IV; (4) calon guru tidak tetap (GTT) yang berasal dari non pendidikan bersedia melaksanakan pendidikan linierisasi jika dibutuhkan. Sedangkan untuk seleksi wawancara hal yang perlu diperhatikan oleh sekolah dalah keadaan fisik calon guru. Guru dituntut untuk tidak memiliki kekurangan fisik yang dapat menghambat kegiatan belajar mengajar (KBM) di sekolah.

Temuan mengenai proses seleksi GTT di Kota Kediri sama dengan teori yang dikemukakan oleh Ulfatin \& Triwiyanto (2016:61) terdapat jenis-jenis metode yang digunakan dalam seleksi pegawai. Salah satu jenis seleksi tersebut adalah : (1) Wawancara, wawancara seleksi adalah diaolog yang dimulai oleh satu atau lebih dari satu orang untuk mengumpulkan informasi dan mengevaluasi berbagai kualifikasi pelamar untuk bekerja; (2) Surat referensi, daftar riwayat hidup, dan formulir lamaran pekerjaan, metode ini merupakan kumpulan dari bukti keandalan yang merupakan referensi sekaligus sebagai alat prediksi untuk keberhasilan dan kegagalan pekerjaan dimasa mendatang.

\section{Kompensasi bagi GTT}

Hasil penelitian menunjukkan bahwa gaji yang diperoleh GTT berasal dari dari dana Bantuan Operasional Sekolah (BOS). Selain itu GTT juga memperoleh insentif tambahan yang bersumber dari APBD Pemerintah Kota Kediri serta GTT juga memperoleh insentif tambahan dari sekolah apabila menjadi pembina kegiatan ekstrakurikuler di sekolah. GTT di Kota Kediri juga mendapatkan asuransi keselamatan kerja melalui kerjasama dengan Badan Penyelenggaran Jaminan Sosial (BPJS) cabang Kediri. Hal ini dilakukan untuk memberikan rasa aman kepada GTT dalam mengabdi pada sekolah. 
Temuan mengenai kompensasi dan keselamatan kerja bagi GTT didukung teori yang dikemukakan oleh Ulfatin dan Triwiyanto (2016:123) sebagai berikut : (1) Gaji dan upah, gaji dan upah umumnya disebut sebagai kompensasi utama karena sebagai gantungan hidup (nafkah) bagi pegawai dan keluarganya; (2) Insentif, insentif dipandang sebagai penghargaan atau ganjaran yang diberikan untuk memotivasi para pegawai agar produktivitas kerjanya semakin tinggi; (3) Jaminan kesehatan dan kesejahteraan, yang tergolong kompensasi jenis ini antara lain: Asuransi jiwa, biaya pengobatan ketika sakit, koperasi (simpan-pinjam), alat-alat keselamatan kerja dan sebagainya.

\section{KESIMPULAN}

Sekolah dalam melakukan analisis kebutuhan perlu memperhatikan anggaran karena sekolah hanya memiliki satu sumber pendapatan yang pada dana Bantuan Operasional Sekolah (BOS). Sekolah dalam melakukan analisis kebutuhan juga perlu memperhatikan kualifikasi guru yang dibutuhkan sekolah, hal ini dikarenakan untuk mengantisipasi supaya sekolah tidak salah dalam melakukan perekrutan GTT.

Dalam proses rekrutmen GTT hal pertama yang dilakukan sekolah adalah mengumumkan lowongan guru kepada warga sekolah. Sekolah tidak mengumumkan lowongan kepada masyarakat luas untuk mengantisipasi banyaknya jumlah pelamar yang ingin mendaftar sebab sekolah tidak memiliki anggaran untuk mengumumkan lowongan kepada media massa. Dalam rekrutmen GTT sekolah juga perlu mempersiapkan sarana dan prasarana yang diperlukan pada saat melakukan perekrutan GTT. Dalam hal ini adalah teknik pelaksanaan dalam perekrutan GTT. Kendala dalam proses rekrutmen adalah banyaknya jumlah pelamar, tidak adanya dasar hukum dalam perekrutan GTT, minimnya anggaran dalam perekrutan GTT serta adanya sistem "titip" bagi pejabat dalam perekrutan GTT.

Proses seleksi terdiri atas seleksi administrasi dan seleksi wawancara. Untuk seleksi administrasi hal-hal yang perlu dipersiapkan oleh pelamar meliputi : (1) Mengajukan lamaran yang ditujukan kepada kepala sekolah, lamaran ditulis pada kertas putih menggunakan tinta hitam (bukan diketik); (2) Calon guru tidak tetap (GTT) memiliki kualifikasi pendidikan Sarjana (S1) sesuai dengan program studi yang butuhkan sekolah, program studi yang dicari sekolah tidak hanya dari mereka yang lulusan pendidikan namun sekolah memberikan peluang kepada pelamar dari program studi non pendidikan; (3) Calon guru tidak tetap (GTT) wajib memiliki akta mengajar yaitu akta IV; (4) Calon guru tidak tetap (GTT) yang berasal dari non pendidikan bersedia melaksanakan pendidikan linierisasi jika dibutuhkan. Sedangkan dalam seleksi wawancara hal yang perlu diperhatikan oleh sekolah dalah keadaan fisik calon guru. Guru dituntut untuk tidak memiliki kekurangan fisik yang dapat menghambat kegiatan belajar mengajar (KBM) di sekolah.

Kompensasi Bagi GTT di Kota Kediri meliputi: (1) kompensasi atau gaji pokok yang diperoleh GTT berasal dari dana Bantuan Operasional Sekolah (BOS). GTT bekerja berdasarkan kontrak kerja dengan jangka waktu 1 tahun; (2) GTT memperoleh insentif tambahan yang bersumber dari APBD Pemerintah Kota Kediri; (3) GTT memperoleh insentif tambahan dari sekolah apabila menjadi pembina kegiatan ekstrakurikuler di sekolah. Sedangkan untuk keselamatan kerja bagi GTT di Kota Kediri juga mendapatkan asuransi keselamatan kerja melalui kerjasama dengan Badan Penyelenggaran Jaminan Sosial (BPJS) cabang Kediri. Hal ini dilakukan untuk memberikan rasa aman kepada GTT dalam mengabdi pada sekolah.

\section{DAFTAR RUJUKAN}

Bafadal,I. 2008. Peningkatan Profesionalisme Guru SD. Jakarta:Bumi Aksara

Hasibuan, M. 2007. Manajemen Dasar, Pengertian dan Masalah. Jakarta:Bumi Aksara

Peraturan Pemerintah Nomor 19 Tahun 2017 tentang Guru. (Online). (sipuu.setkab.go.id/puu/buka.../PP\%20 19\%20Tahun\%202017.pdf), diakses 1 November 2017

Roqib, M \& Nurfuadi. 2009. Kepribadian Guru. Yogyakarta: Grafindo Litera Media

Simamora,H. 2006. Manajemen Sumber Daya Manusia Edisi III.Yogyakarta:STIE YKPN 
Sunandar, A. 2006. Analisis Perencanaan Kebutuhan Guru. Jurnal Manajemen Pendidikan, 02(01),1---11. Dari https://media.neliti.com/media/publications/114117-ID-analisis-perencanaan-kebutuhan-guru.pdf

Ulfatin,N \& Triwiyanto,T. 2016. Manajemn Sumber Daya Manusia Bidang Pendidikan. Jakarta: PT Raja Grafindo Persada.

Undang-Undang Republik Indonesia Nomor 14 Tahun 2005 tentang Guru dan Dosen.(online),( luk.staff.ugm. ac.id/atur/UU14-2005GuruDosen.pdf), diakses 22 November 2017

Undang-Undang Republik Indonesia Nomor 5 Tahun 2014 tentang Aparatur Sipil Negara.(online), (https://luk. staff.ugm.ac.id/atur/UU5-2014AparaturSipilNegara.pdf), diakses 15 Oktober 2017

Wijayanti \& Sutapa. 2015. Penataan dan Pemerataan Guru : Analisis Kebutuhan, Ketersediaan dan Kecukupan Guru di Kabupaten Purbalingga Jawa Tengah. Jurnal Teknodika. 13 (1). Dari www.jurnal.fkip.uns.ac.id/ index.php/teknodika/article/.../4637 